\title{
Importance of the Autumn Overturn and Anoxic Conditions in the Hypolimnion for the Annual Methane Emissions from a Temperate Lake
}

\author{
Jorge Encinas Fernández, Frank Peeters, and Hilmar Hofmann* \\ Environmental Physics, Limnological Institute, University of Konstanz, Mainaustr. 252, D 78464 Konstanz, Germany \\ Supporting Information
}

\begin{abstract}
Changes in the budget of dissolved methane measured in a small temperate lake over 1 year indicate that anoxic conditions in the hypolimnion and the autumn overturn period represent key factors for the overall annual methane emissions from lakes. During periods of stable stratification, large amounts of methane accumulate in anoxic deep waters. Approximately $46 \%$ of the stored methane was emitted during the autumn overturn, contributing $\sim 80 \%$ of the annual diffusive methane emissions to the atmosphere. After the overturn period, the entire water column was oxic, and

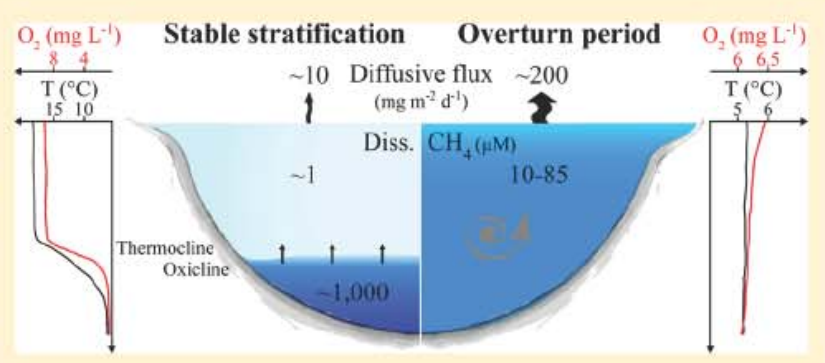
only $1 \%$ of the original quantity of methane remained in the water column. Current estimates of global methane emissions assume that all of the stored methane is released, whereas several studies of individual lakes have suggested that a major fraction of the stored methane is oxidized during overturns. Our results provide evidence that not all of the stored methane is released to the atmosphere during the overturn period. However, the fraction of stored methane emitted to the atmosphere during overturn may be substantially larger and the fraction of stored methane oxidized may be smaller than in the previous studies suggesting high oxidation losses of methane. The development or change in the vertical extent and duration of the anoxic hypolimnion, which can represent the main source of annual methane emissions from small lakes, may be an important aspect to consider for impact assessments of climate warming on the methane emissions from lakes.
\end{abstract}

\section{INTRODUCTION}

Lakes are an important component of the global carbon cycle because they store and release substantial amounts of carbon dioxide ${ }^{1,2}$ and are a particularly important source of methane in the global methane budget. ${ }^{3-5}$ According to Bastviken et al., ${ }^{6}$ most of the methane originating from lakes occurs in small lakes $\left(<10 \mathrm{~km}^{2}\right)$, which release more methane per unit area than large lakes. ${ }^{3,7}$ Although recent estimates of the lake size distribution suggest that the area of small lakes is only $\sim 26 \%$ of the total global lake area, ${ }^{8}$ methane emissions from small lakes still contribute a major fraction of global methane emissions from lakes.

Estimates of global methane emissions from lakes typically distinguish between three pathways of methane release from the water body to the atmosphere: diffusive fluxes, ebullition, and release of stored methane. ${ }^{6}$ Additionally, plant mediated fluxes may also be an important pathway of methane emissions from lakes. ${ }^{9,10}$ In lakes, methane is a major product of carbon cycling, ${ }^{11}$ and most of the methane is produced within the sediments. A large proportion of this methane is removed by aerobic oxidation at oxic sediment-water interfaces or oxyclines within the water column ${ }^{12}$ or by anaerobic oxidation. ${ }^{13}$ Some of the methane is stored in the water column. In lakes with an anoxic hypolimnion, large amounts of dissolved methane can accumulate, which leads to a particularly large quantity of stored methane. ${ }^{3,14-16}$ In monomictic and dimictic lakes, methane stored in anoxic hypolimnia can be released during periods of rapid vertical mixing (overturns) that occur once or twice a year, respectively. During overturn periods, the accumulated dissolved methane is redistributed over the entire water column, which can result in high diffusive methane fluxes to the atmosphere. ${ }^{15,17,18}$ According to Bastviken et al., ${ }^{3}$ the contribution of the stored methane to the overall annual methane emissions (the "storage flux") increases with decreasing lake size and reaches approximately $45 \%$ in small lakes. However, this estimate assumes that all of the stored methane is released to the atmosphere. Conversely, several other studies ${ }^{15,18,19}$ have claimed that most of the stored methane is oxidized in the water column during the overturn period. This suggests that a major contribution to the estimate of annual methane emissions from small lakes may have been substantially overestimated.

Most of the studies that have investigated fluxes of stored methane have focused on the autumn overturn and its contribution to the overall annual methane emissions. ${ }^{3}$ Recently, additional studies have investigated methane emissions during the spring overturn or spring and autumn

Received: December 17, 2013

Revised: May 26, 2014

Accepted: May 29, 2014

Published: May 29, 2014 
overturns. ${ }^{7,17,20}$ For example, López Bellido et al. ${ }^{17}$ investigated the methane emissions from a dimictic boreal lake with an oxic water column and concluded that the amount of methane emitted during spring overturns after ice breakup is larger than that emitted during autumn overturns. On the basis of methane budgets from numerous Finnish boreal lakes, Juutinen et al. ${ }^{7}$ found that the storage fluxes of methane were usually larger in spring than in autumn, but in some of the lakes, the methane fluxes in autumn were larger than those in spring.

In the present study, we investigated the dynamics of dissolved methane over an entire year in a small temperate dimictic lake that develops an anoxic hypolimnion during summer stratification and compared the diffusive methane fluxes from different time periods: the stratified period in summer, the autumn overturn, the winter mixing period, and the period from spring to summer stratification. On the basis of these data, we discuss the relative importance of autumn and spring mixing for the overall methane release from lakes and demonstrate the important role of methane stored in an anoxic hypolimnion to the overall methane budgets of lakes. Further, we discuss potential implications of climate warming and associated changes in the physical conditions related to methane emissions from lakes.

\section{MATERIALS AND METHODS}

Measurements were conducted in Mindelsee (location $47^{\circ} 45.178^{\prime} \mathrm{N}, 9^{\circ} 1.423^{\prime} \mathrm{E}$; area $1.02 \mathrm{~km}^{2}$; maximum depth $13.5 \mathrm{~m}$ ), which is located near Lake Constance in southern Germany. Mindelsee is a small mesotrophic dimictic lake that mixes twice a year: in autumn (end of October to beginning of December) after the summer stratification and early spring (March) after the inverse stratification during ice coverage. ${ }^{21}$

Field measurements of the dissolved methane concentration and abiotic parameters were conducted between July 2012 and June 2013 at the maximum depth near the center of the lake [see Figure S1 in the Supporting Information (SI)]. During the stratified period, sampling was conducted at least once a month but mostly once every 2 weeks. Shortly before, during, and after the autumn overturn, samples were collected every $2-3$ days to resolve short term temporal changes of the dissolved methane concentration. On each of the sampling dates, water samples were taken at water depths from 1 to $13 \mathrm{~m}$ with a vertical resolution of $1 \mathrm{~m}$ using a $2 \mathrm{~L}$ sampler (Limnos) and then transferred into $122 \mathrm{~mL}$ serum bottles. The sampling procedure has been described in detail by Hofmann et al. ${ }^{22}$ Vertical profiles of depth, temperature, and oxygen were collected with a multiparameter probe (CTD probe, RBR Ltd., Ottawa, Canada; fast oxygen optode 4330F, AANDERAA, Bergen, Norway) at a sampling frequency of $6 \mathrm{~Hz}$. Each profile (downcast) took at least $20 \mathrm{~min}$ and corresponded to a vertical resolution of $<0.01 \mathrm{~m}$. During the stratified period in summer (10 August 2012) and during the autumn overturn period (7 December 2012), additional water samples were collected at a water depth of $1 \mathrm{~m}$ along the main axis of the basin $(\sim 150-450$ $\mathrm{m}$ horizontal resolution; Figure S1 in the SI).

The dissolved methane concentration of the water samples was analyzed using a headspace method by following the procedure described in detail by Hofmann et al. ${ }^{22}$ The methane concentration in the headspace was measured by gas chromatography with flame ionization detection (GC FID) (GC 6000, Carlo Erba Instruments). Gas standards of 10, 50, and $100 \mathrm{ppm}$ (Air Liquide) were used to calibrate the GC data. The calibration was repeated for every five water samples and used for the subsequent samples. On average, the concentration measurements of replicate samples varied by $<5 \%$.

The total mass of dissolved methane stored in the water column was calculated by integration of the volume weighted concentrations available at $1 \mathrm{~m}$ depth intervals (hypsographic curves of Mindelsee; Figure S2 in the SI).

The diffusive flux of methane to the atmosphere was calculated using the boundary layer model as described by Liss and Slater: ${ }^{23}$

$$
F_{\mathrm{CH}_{4}}=k_{\mathrm{CH}_{4}} \cdot M_{\mathrm{CH}_{4}} \cdot\left(C_{\mathrm{w}}-C_{\mathrm{eq}}\right)
$$

where $\mathrm{F}_{\mathrm{CH}_{4}}$ is the air-water flux of methane, $k_{\mathrm{CH}_{4}}$ is the transfer velocity of methane, $M_{\mathrm{CH}_{4}}$ is the molar mass of methane, $C_{w}$ is the measured near surface water molar concentration of methane, and $C_{\text {eq }}$ is the molar concentration of methane in the surface water that is in equilibrium with the atmospheric concentration at surface water temperatures. The transfer velocity of methane, $k_{\mathrm{CH}_{4}}$, was estimated from $k_{600}$, the transfer velocity of $\mathrm{CO}_{2}$ under standard conditions (a Schmidt number of 600), using the equation of Liss and Merlivat: ${ }^{24}$

$$
k_{\mathrm{CH}_{4}}=k_{600} \cdot\left(\frac{S c}{600}\right)^{n}
$$

in which $S_{c}$ is the Schmidt number of methane at water surface temperatures ${ }^{25}$ and $n$ is $-2 / 3$ for $U_{10} \leq 3.7 \mathrm{~m} \mathrm{~s}^{-1}$ and $-1 / 2$ for $U_{10}>3.7 \mathrm{~m} \mathrm{~s}^{-1}$, where $U_{10}$ is the wind speed at an elevation of $10 \mathrm{~m}$. The gas transfer velocity $k_{600}\left(\right.$ in $\left.\mathrm{cm} \mathrm{h}^{-1}\right)$ was calculated using the equation of Cole and Caraco, ${ }^{26}$

$$
k_{600}=2.07+0.215 \cdot U_{10}{ }^{1.7}
$$

as well as the equations of Crusius and Wanninkhof, ${ }^{27}$ Guerin et al., ${ }^{28}$ and MacIntyre et al. ${ }^{29}$ (eqs S4-S6 in the SI). $C_{\text {eq }}$ for methane was calculated according to Wiesenburg and Guinasso, ${ }^{30}$ wherein the atmospheric concentration of methane was set to $1.8 \mathrm{ppm}$. Wind data $\left(U_{10}\right.$ in $\left.\mathrm{m} \mathrm{s}^{-1}\right)$ were supplied by a nearby (15 km east of Mindelsee) meteostation (Konstanz) of the German Weather Service (DWD). During the study, no meteostation was installed on Mindelsee, but earlier measure ments showed that wind speeds measured at the DWD Konstanz station are in close agreement with the wind speeds measured on Mindelsee [in 2011, the wind speeds (mean \pm SD) measured on Mindelsee and at station Konstanz were 2.08 \pm 1.34 and $2.09 \pm 1.27 \mathrm{~m} \mathrm{~s}^{-1}$, respectively]. The near surface concentration of dissolved methane, water temperature, and wind speed were assumed to be homogeneous over the entire lake surface. The time series of the dissolved methane concentration and surface water temperature were linearly interpolated to the time series of the wind speed (temporal resolution of $1 \mathrm{~h}$ ). These estimates of the diffusive methane flux were employed as losses in the mass balance of methane. Ebullition and plant mediated fluxes were not measured and are not included in the above estimates of methane losses; therefore, they can be considered as lower limits of the total overall methane emissions.

In addition to the water sampling for methane analysis in the lab, a methane probe (HydroC/ $\mathrm{CH}_{4}$ probe, Contros Systems \& Solutions, Kiel, Germany) was deployed at a depth of $2 \mathrm{~m}$ between 22 October and 16 December 2012, covering the entire overturn period. The probe measured the concentration of dissolved methane in situ at a sampling interval of $1 \mathrm{~Hz}$ and provided a continuous and high resolution time series of 


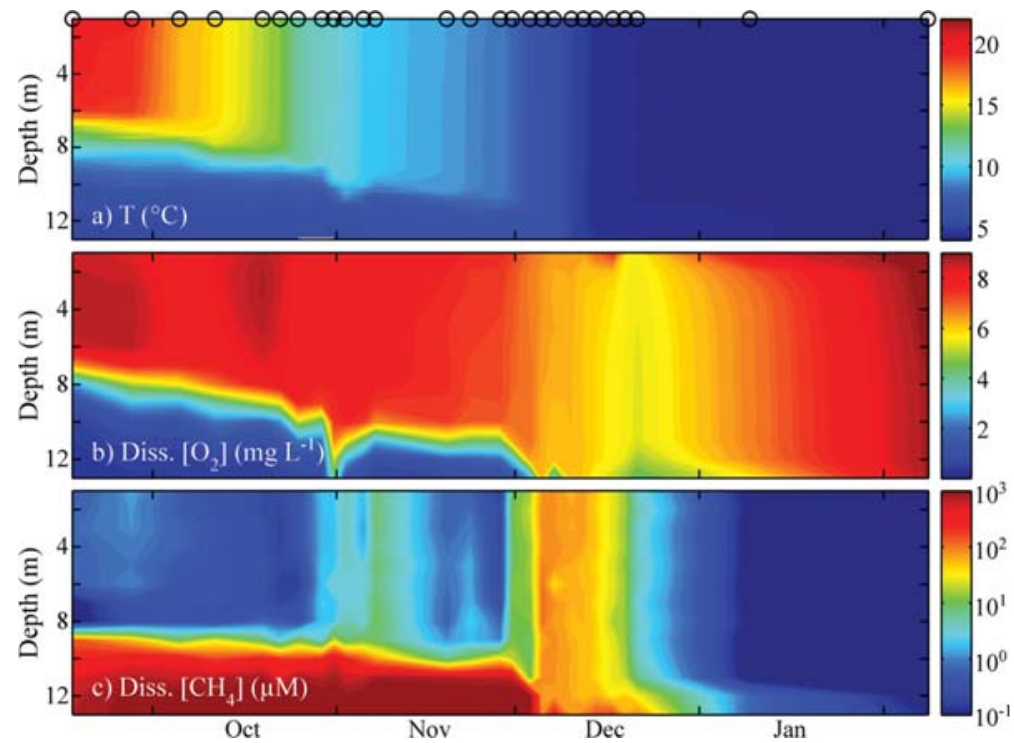

Figure 1. Temporal variability of the water column in Mindelsee for (a) the temperature, (b) the dissolved oxygen concentration, and (c) the dissolved methane concentration at the deepest point before, during, and after the autumn overturn ( 7 September 2012 to 8 February 2013). The black circles at the top of panel (a) indicate the sampling dates.

\section{Table 1. Mass Balance of Methane in Mindelsee ${ }^{a}$}

\begin{tabular}{|c|c|c|c|c|c|c|c|}
\hline \multirow{3}{*}{ time period } & \multicolumn{3}{|c|}{ rates } & \multicolumn{4}{|c|}{ total mass of $\mathrm{CH}_{4}$} \\
\hline & \multirow[t]{2}{*}{$\begin{array}{l}\text { temporal change of stored } \mathrm{CH}_{4} \\
\qquad\left(\mathrm{~kg} \mathrm{day}^{-1}\right)\end{array}$} & \multicolumn{2}{|c|}{ diffusive $\mathrm{CH}_{4}$ flux } & \multicolumn{3}{|c|}{ water column storage $(\mathrm{kg})$} & \multirow[t]{2}{*}{$\begin{array}{l}\text { emitted } \mathrm{CH}_{4} \\
(\mathrm{~kg})\end{array}$} \\
\hline & & $\left(\mathrm{mg} \mathrm{m}^{-2}\right.$ day $\left.^{-1}\right)$ & $\overline{\left(\mathrm{kg} \mathrm{day}^{-1}\right)}$ & beginning & end & diff. & \\
\hline $07 / 18 / 12 \quad 10 / 25 / 12$ & 142.5 & 10.1 & 10.3 & 4299 & 18549 & 14250 & 1026 \\
\hline $10 / 25 / 12 \quad 11 / 28 / 12$ & 5.1 & 23.5 & 23.9 & 18549 & 18721 & 172 & 814 \\
\hline $11 / 28 / 12 \quad 01 / 09 / 13$ & 445.3 & 202.1 & 206.1 & 18721 & 17 & 18704 & 8657 \\
\hline $01 / 09 / 13 \quad 05 / 24 / 13$ & 1.1 & 1.3 & 1.3 & 17 & 137 & 120 & 135 \\
\hline $05 / 24 / 13 \quad 06 / 24 / 13$ & 18.7 & 4.8 & 4.9 & 137 & 699 & 562 & 148 \\
\hline total & & & & & & & 10788 \\
\hline
\end{tabular}

${ }^{a}$ The temporal change of dissolved methane stored in the entire water column and the diffusive methane flux to the atmosphere are shown for different time periods in 2012-13: stratification period from 18 July to 25 October 2012; first mixing event from 25 October to 28 November 2012 ; overturn period from 28 November 2012 to 9 January 2013; winter mixing period from 9 January to 24 May 2013; and the beginning of stratification from 24 May to 24 June 2013. Also included are the total masses of methane in the water column at the beginning and end of each period and the corresponding differences and the total amounts of methane emitted by diffusion to the atmosphere during the different time periods. The mass balance of methane is based on the diffusive flux estimates, which are derived from the equation for the gas transfer velocity given by Cole and Caraco. $^{26}$

dissolved methane concentrations between the regular sampling dates. Gaps in the time series of the probe were caused by battery replacements and related losses in the power supply (the probe has a high power consumption of $\sim 15-20$ $\mathrm{W}$ ). The probe was calibrated by means of a linear fit between the log transformed dissolved methane concentrations meas ured in the water samples collected at a depth of $2 \mathrm{~m}$ and probe data measured at the same time at a depth of $2 \mathrm{~m}$ (Figure S3 in the SI). The diffusive flux of methane was estimated using the data from the methane probe, and this value was compared to the diffusive methane flux calculated from the dissolved methane concentrations measured in the water samples taken at a water depth of $2 \mathrm{~m}$.

In addition to the mass balance of methane, the mass balance of oxygen was calculated by integrating the volume weighted oxygen concentrations and considering gas exchange of oxygen between the lake and the atmosphere. The gas exchange at the lake surface was calculated using the same boundary layer model as for methane ${ }^{23}$ by replacing the Schmidt number of methane with that of oxygen. ${ }^{25}$ The oxygen mass balance was applied to three time periods to provide the oxygen demand of the lake between 8 February and 24 April 2013, when the lake was mixed and oxic; between 25 April and 24 May 2013, when the lake was stratified and oxic; and for the overturn period between 28 November 2012 and 9 January 2013. On the basis of the oxygen concentrations between April and May 2013, when the entire water column was oxic, the areal and volumetric oxygen demands $\left(O_{\mathrm{A}}\right.$ and $O_{\mathrm{V}}$, respectively) were crudely estimated. Details about this calculation are given in the SI.

\section{RESULTS}

From summer to autumn 2012, the lake was stably stratified (Figure 1a and Figure S5a in the SI). The water column was saturated with oxygen down to $\sim 6 \mathrm{~m}$, whereas the oxygen concentration gradually decreased to $<1 \mathrm{mg} \mathrm{L}^{-1}$ below $10 \mathrm{~m}$. Therefore, during the stable stratification, the hypolimnion was characterized by hypoxic and anoxic conditions (Figure $1 \mathrm{~b}$ ). 


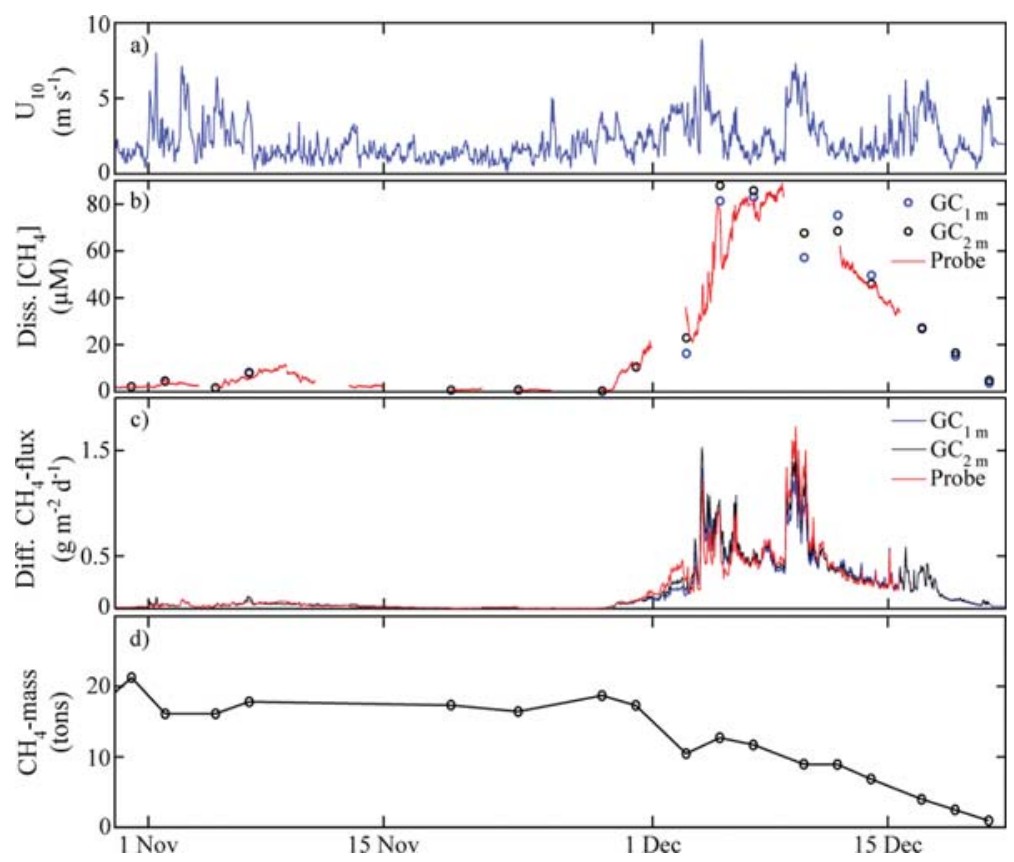

Figure 2. Temporal courses of (a) the wind speed ( $U_{10}$ measured at a proximal meteostation, DWD Konstanz), (b) the dissolved methane concentration as measured by GC analysis of water samples collected at depths of $1 \mathrm{~m}$ (blue circles) and $2 \mathrm{~m}$ (black circles) using the headspace technique and by an in situ methane probe (red line) at a water depth of $2 \mathrm{~m}$ at the deepest point of Mindelsee, (c) the diffusive flux of methane calculated by a boundary layer model from the water samples collected at $1 \mathrm{~m}$ (blue line) and $2 \mathrm{~m}$ (black line) and probe data (red line), and (d) the mass of dissolved methane stored in the entire water column between 31 October and 21 December 2012.

The epilimnetic dissolved methane concentrations were low and ranged between 0.5 and $1 \mu \mathrm{M}$, whereas the dissolved methane concentrations in the anoxic deep water zone were extremely high and reached $\sim 1400 \mu \mathrm{M}$ (Figure 1c and Figure S5a,b in the SI). The total mass of dissolved methane stored in the entire water column increased continuously during the stratification period because of the methane accumulation of $\sim 4.3$ to $\sim 18.5$ tons in the anoxic hypolimnion from 18 July to 25 November, respectively, which was just prior to the autumn overturn (Table 1 and Figure S5a,b in the SI). During this time, the mean diffusive flux of methane from the lake was $10.1 \mathrm{mg}$ $\mathrm{m}^{-2}$ day $^{-1}$. In total, the lake emitted $\sim 1030 \mathrm{~kg}$ of methane to the atmosphere (Table 1 and Figure 1c).

Between the end of September and the end of October 2012, the epilimnion cooled down, which led to a decrease in the density difference between the epilimnion and hypolimnion (Figure 1a). Increased mixing in the surface layer resulted in a deepening of the thermocline and oxycline down to $\sim 10 \mathrm{~m}$ (Figure 1a,b). Between 25 October and 28 November, the stratification was already weak. At the beginning of this period, several days with high wind speeds $\left(U_{10}=5-8 \mathrm{~m} \mathrm{~s}^{-1}\right.$ and annual mean $U_{10}=2.2 \mathrm{~m} \mathrm{~s}^{-1}$ ) caused an initial short duration major mixing of the water column down to a depth of $\sim 11 \mathrm{~m}$ (Figures 1 and 2a and Figure S5b in the SI). Over the 35 days, the dissolved methane concentration in the upper mixed water column increased from $\sim 2.1$ to $\sim 8.2 \mu \mathrm{M}$, which also increased the diffusive flux to the atmosphere from $\sim 10$ to $\sim 24 \mathrm{mg} \mathrm{m}^{-2}$ day $^{-1}$. During this time period, the lake emitted $\sim 814 \mathrm{~kg}$ of methane, which was only slightly less than the emission during the previous 98 days (Table 1). Thereafter, the water column was stratified again until the end of November, and the dissolved methane concentration in the epilimnion decreased to $\sim 0.5 \mu \mathrm{M}$ (Figures $1 \mathrm{c}$ and $2 \mathrm{~b}$ ).
On 28 November 2012, the stratification was already rather weak, and a slight wind $\left(U_{10}<3 \mathrm{~m} \mathrm{~s}^{-1}\right)$ was sufficient to mix the methane rich water from the upper part of the hypolimnion into the upper mixed layer, wherein the dissolved methane concentration increased to $\sim 10 \mu \mathrm{M}$. On 3 December, a strong wind event $\left(U_{10}>9 \mathrm{~m} \mathrm{~s}^{-1}\right)$ mixed all of the dissolved methane stored in the hypolimnion $(\sim 10 \%$ of the total lake volume) into the water column (Figure 1c and Figures S2 and S5c in the SI) and also mixed the dissolved oxygen downward, which resulted in oxic conditions throughout the entire water column (Figure $1 \mathrm{~b}$ and Figure S5c in the SI). The near surface dissolved methane concentration reached maximum values of $>80 \mu \mathrm{M}$ for several days and values of $>20 \mu \mathrm{M}$ for about 2 weeks (Figures $1 \mathrm{c}$ and $2 \mathrm{~b}$ ). These high dissolved methane concentrations at the lake surface led to high diffusive fluxes of up to $1500 \mathrm{mg} \mathrm{m}^{-2}$ day $^{-1}$ (Figure 2c), especially during periods of high wind speed (Figure 2a). On average, the diffusive flux for the entire overturn period (28 November 2012 to 9 January 2013) was $\sim 200 \mathrm{mg} \mathrm{m}^{-2}$ day $^{-1}$. In total, $\sim 8.7$ tons of methane was emitted to the atmosphere during the overturn period (Table $1)$.

On 9 January 2013, which was after the overturn period, the temperature, oxygen, and methane profiles were vertically homogeneous, suggesting that the lake was well mixed (Figure S5d in the SI). In winter, the lake was only intermittently ice covered. A hypoxic deep water layer did not develop, and the dissolved methane concentrations in the entire water column were $\sim 0.1-0.2 \mu \mathrm{M}$ (Figure 1c) and remained at these low values until 24 May 2013. During this period, the diffusive flux of methane was on average $\sim 1.3 \mathrm{mg} \mathrm{m}^{-2} \mathrm{day}^{-1}$, and the emitted methane mass amounted to only $\sim 140 \mathrm{~kg}$ (Table 1 ). At the end of May, the water column became restratified. One month later, on 24 June, the deep layer of the water column 
was again anoxic and contained high concentrations of dissolved methane (Figure S5e in the SI). The dissolved methane concentration in the upper mixed layer increased to $\sim 0.6 \mu \mathrm{M}$, and the diffusive flux of methane increased to $\sim 4.8$ $\mathrm{mg} \mathrm{m}^{-2}$ day $^{-1}$. Between 24 May and 24 June, $\sim 150 \mathrm{~kg}$ of methane was emitted to the atmosphere (Table 1).

The diffusive fluxes of methane to the atmosphere were not only calculated according to the gas transfer velocity equation of Cole and Caraco ${ }^{26}$ (Table 1) but also using the equations of Crusius and Wanninkhof, ${ }^{27}$ Guerin et al., ${ }^{28}$ and MacIntyre et al. $^{29}$ (Tables S1-S3 in the SI). The diffusive emissions obtained from the equations of Guerin et $\mathrm{al}^{28}$ and Crusius and Wanninkhof ${ }^{27}$ were consistent with the diffusive emissions obtained using the equation of Cole and Caraco. ${ }^{26}$ The overall diffusive methane emissions based on the equations of Crusius and Wanninkhof ${ }^{27}$ and Guerin et al. ${ }^{28}$ were $\sim 5 \%$ and $\sim 8 \%$ larger, respectively. The emissions obtained using the equation of MacIntyre et al. ${ }^{29}$ were substantially larger than those obtained using all of the other relationships.

The methane probe was well suited to measure the methane concentration reliably over long time periods at a high temporal resolution (Figure $2 \mathrm{~b}$ ). The probe data indicated variations in the methane concentration over short time intervals that would not have been detected solely by water sampling (Figure $2 b$ ). Although the probe data provide additional details on the temporal course of the near surface dissolved methane concentration (Figure 2b), the diffusive methane fluxes estimated from the probe data and water samples are similar $\left(R^{2}=0.97\right.$ and $p<0.001$; Figure $\left.2 \mathrm{c}\right)$, indicating that the temporal resolution of $\sim 3$ days of sampling during the overturn period is sufficient to resolve the diffusive methane emissions from lakes.

The oxygen mass balance indicated that the oxygen demand of the lake was $\sim 0.8$ ton day ${ }^{-1}$ between February and April 2013 and between April and May 2013, when the lake was oxic. During the overturn period, the oxygen demand was $\sim 3.2$ ton $\mathrm{day}^{-1}$ and thus was substantially larger than in the two other time periods. During the overturn, the influx of oxygen was $\sim 3.2$ ton day $^{-1}$ and thus was the major source of oxygen. During the stratified period in spring when the water column was oxic, the volumetric oxygen uptake $\left(O_{\mathrm{V}}\right)$ was $\sim 0.08 \mathrm{~g} \mathrm{~m}^{-3}$ day $^{-1}$ and the oxygen uptake by oxic sediment $\left(O_{\mathrm{A}}\right)$ was $\sim 0.13$ $\mathrm{g} \mathrm{m}^{-2}$ day $^{-1}$. During the overturn period, $\sim 10$ tons of stored methane was not emitted to the atmosphere but was lost from the water column (Table 1). Explaining this loss of methane by oxidation implies that $\sim 40$ tons of oxygen was removed during the overturn period as a result of methane oxidation.

\section{DISCUSSION}

The measurements sufficiently resolved the vertical distribution and annual course of methane, especially before, during, and after the autumn overturn. The detailed investigation of the methane budget from mass balance calculations supports the conclusions that methane emissions from lakes via the diffusive flux pathway vary substantially over a year and a major fraction of the annual methane emissions can be released during a rather short time period of approximately 1 month, such as in the case of Mindelsee during the autumn overturn. It should be noted that ebullition and plant mediated fluxes were not measured or included in our estimates of the methane emissions from Mindelsee.

The stratification period between 18 July and 25 October 2012 was characterized by a significant increase of $\sim 140 \mathrm{~kg}$ day $^{-1}$ in the amount of methane dissolved in the water column (Table 1), which was predominantly a result of an increase of methane in the anoxic deep water (Figure 1c). The accumulation of large amounts of dissolved methane during the stratified period has been observed in several lakes with an anoxic hypolimnion. ${ }^{3,16}$ Despite the large amounts of methane stored in the water column, the methane concentrations at the lake surface remained rather low, which suggests that the methane that is transported vertically from the deep methane rich anoxic layer is oxidized efficiently in the transition zone between the anoxic and oxic waters ${ }^{12,13}$ at water depths of $\sim 8-$ $10 \mathrm{~m}$. Because of the very low surface concentrations of methane, the diffusive flux to the atmosphere was only $\sim 10 \mathrm{mg}$ $\mathrm{m}^{-2}$ day $^{-1}$ during the stratified period (Table 1 ).

In late autumn (between 25 October and 28 November 2012), high wind speeds (up to $\sim 5-9 \mathrm{~m} \mathrm{~s}^{-1}$ ) were responsible for an initial substantial increase in the diffusive flux of methane from the lake for two reasons: the wind forcing caused a mixing event in which the dissolved methane was rapidly transported from the hypolimnion to the epilimnion and increased the dissolved methane concentration in the upper part of the water column (Figure 1c), which increased the gradient between the dissolved and atmospheric equilibrium methane concentra tions; and high winds reduced the thickness of the diffusive boundary layer at the air-water interface, which indicates that such winds are associated with high gas transfer velocities. Both of the wind forcing effects increased the diffusive flux of methane to the atmosphere to a value of $\sim 24 \mathrm{mg} \mathrm{m}^{-2}$ day $^{-1}$ (Table 1). Despite the comparatively high losses of methane to the atmosphere and the potential for additional losses as a result of the oxidation of methane in the oxic water of the metalimnion and epilimnion, the methane stored in the water column still increased slightly by $\sim 5 \mathrm{~kg} \mathrm{day}^{-1}$ during this time period (Table 1 and Figure 2d), which indicates that increased losses of methane to the atmosphere are not necessarily reflected in a decrease in methane stored in the water column. However, the accumulation rate during the mixing event was $\sim 28$ times less than during the previous time period (Table 1). This may be partially explained by oxidation of the methane transported from the deep anoxic waters to the oxic water layers; however, it may also be explained by a reduced flux of methane from the sediments into the water column as a result of the reduced (by 35\%; Figures S1 and S2 in the SI) area of anoxic sediment surfaces in contact with the water column where the methane produced within the sediments can pass into the water column without being oxidized.

Between 28 November 2012 and 9 January 2013, the autumn overturn redistributed the dissolved methane and oxygen within the entire water column (Figure $1 b, c$ ). The occurrence of rapid mixing is supported by the nearly homogeneous vertical profiles of methane, dissolved oxygen, and temperature (Figure S5c in the SI). Vertical transport during the autumn overturn was sufficiently fast and caused high dissolved methane concentrations in the upper water layer and diffusive methane fluxes to the atmosphere of $\sim 200 \mathrm{mg} \mathrm{m}^{-2}$ day $^{-1}$ (average during the main overturn period; Table 1). Compared with the methane emitted during the rest of the year $(\sim 10 \mathrm{mg}$ $\mathrm{m}^{-2}$ day $^{-1}$ during summer, $\sim 1 \mathrm{mg} \mathrm{m}^{-2}$ day $^{-1}$ during the winter mixing period, and $\sim 5 \mathrm{mg} \mathrm{m}^{-2}$ day $^{-1}$ during the beginning of stratification; Table 1), the high diffusive methane fluxes during the overturn period demonstrate the importance of this time period in the annual methane emissions to the atmosphere. 
After the autumn overturn, only $\sim 1 \%$ of the methane stored in the water column at the end of the stratified period remained in the water column (Table 1 and Figure 2d). Therefore, 99\% of the stored methane was emitted to the atmosphere or oxidized in the water column during the autumn overturn period, and $\sim 46 \%$ of this methane was emitted to the atmosphere by diffusion (Table 1).

In the mass balance calculations, we assumed that the diffusive methane flux based on the conditions in the middle of the lake is representative of the average methane flux from the lake. This assumption is supported by the comparatively small horizontal variation of methane concentrations measured along the main axis of the lake (Figure S6 in the SI), especially during the overturn period, in which the major fraction of the annual methane emission from the lake is contributed. The methane concentration in the middle of the lake (permanent sampling station) differed from the mean concentration along the transect by only 5\% during the overturn period (on 7 December 2012) and $\sim 18 \%$ in summer (on 10 August 2012). During the overturn period, the data do not show a directed gradient between the nearshore and offshore zones or a significant correlation between the methane concentration and water depth. In summer, an offshore directed gradient in the near surface dissolved methane concentration was observed, which was suggested by earlier studies. ${ }^{22,31}$ However, the relative importance of the higher spatial heterogeneity of the dissolved methane concentration in summer compared with the overturn period of annual emissions was small because only a minor fraction of the methane is emitted during the stable stratification in summer.

According to the flux chamber measurements (diffusive fluxes only) of Schilder et al., ${ }^{32}$ the gas transfer velocity calculated from the empirical relationship of Cole and Caraco ${ }^{26}$ is fairly consistent with or a slight underestimate of the average whole lake gas transfer velocity in lakes with a surface area of $\sim 1 \mathrm{~km}^{2}$ (see Figure 3e in ref 32). Hence, the diffusive fluxes of methane determined here from the empirical relationship of Cole and Caraco ${ }^{26}$ for Mindelsee, which has a surface area of $1.02 \mathrm{~km}^{2}$, can be considered as representative or a slight underestimate of the average lake wide diffusive emissions from the lake.

Independent of the choice of the model for the gas transfer velocity, about half or more of the stored methane is released to the atmosphere; according to the equations of Crusius and Wanninkhof, ${ }^{27}$ Cole and Caraco, ${ }^{26}$ Guerin et al., ${ }^{28}$ and MacIntyre et al., ${ }^{29}$ the amounts are $~ 49 \%, \sim 46 \%, \sim 50 \%$, and $\sim 87 \%$, respectively (Table 1 and Tables $\mathrm{S} 1-\mathrm{S} 3$ in the SI). Except for the model of MacIntyre et al., ${ }^{29}$ which suggests very high methane emissions, these relationships provide similar results, indicating that $46-50 \%$ of the stored methane is released to the atmosphere. Our study is based on the values derived from the relationship of Cole and Caraco, ${ }^{26}$ which represent the lowest methane emissions. The amount of methane released from Mindelsee during the autumn overturn is not sensitive to deviations in the wind speed $\left(U_{10}\right)$. With the assumption that the true wind speed on the lake differed by $\pm 10 \%$ from that at the measuring station, the proportion of stored methane released to the atmosphere changed by only $\pm 4 \%$. The above sensitivity studies support the conclusion that during the autumn overturn, about half of the methane stored in the water column is released to the atmosphere and the other half may be oxidized within the water column. This conclusion is in contrast to those of several other studies, ${ }^{15,18,19}$ which claimed that most of the stored methane is oxidized (74-88\%). For example, Schubert et al. ${ }^{15}$ concluded that in temperate Rotsee, $75 \%$ of the stored methane was oxidized and only $25 \%$ was emitted to the atmosphere during the overturn period. It should be noted that all of the overturn events studied by Schubert et al. ${ }^{15}$ were events with incomplete mixing, such as in an anoxic deep water layer with high methane concentrations. In the case of Mindelsee, we documented an event with partial mixing and a main overturn event in which the entire water column, including the sediment-water interface in the deep water, became oxic. The different conditions at the sedimentwater interface have strong implications for the methane flux from the sediments to the water column. When the deep water was anoxic, the amount of stored methane significantly increased (between 18 July and 25 October 2012; Table 1). In contrast, when the sediment surface was oxic, the amount of stored methane was small and nearly constant (between 9 January and 24 May 2013; Table 1). The overturn event in Mindelsee might have been so effective that it resulted in the emission of $\sim 46 \%$ of the stored methane as a result of intense mixing that created large methane gradients at the air-water interface. These in turn led to high diffusive fluxes to the atmosphere. In addition, the intense vertical mixing associated with the overturn creates oxic conditions at the sedimentwater interface, which result in a low flux of methane from the sediments into the water column because of the enhancement of methanotrophy.

Because Rotsee and Mindelsee have similar morphometries and trophic states and both are located in temperate zones, similar oxidation rates of stored methane during overturns in these lakes might be expected. In Mindelsee, $\sim 135$ tons of oxygen was consumed during the overturn period (Figure S4 in the SI). The oxidation of the 10 tons of stored methane that was not emitted but was lost from the water column required $\sim 40$ tons of oxygen. Oxygen uptake by sediments and in the volume removed 35 tons of oxygen if one assumes that $O_{\mathrm{A}}=$ $0.13 \mathrm{~g} \mathrm{~m}^{-2}$ day $^{-1}$ and $O_{\mathrm{V}}=0.08 \mathrm{~g} \mathrm{~m}^{-3}$ day $^{-1}$. However, $\sim 60$ tons of oxygen uptake remains unexplained by this calculation. According to Frevert, ${ }^{33}$ the areal demand of anoxic sediments during reoxidation can be about 4 times the uptake by oxic sediments, which would explain the uptake of an additional 17 tons of oxygen. The remaining $\sim 43$ tons of oxygen loss may be explained by the oxidation of reduced substances (e.g., $\mathrm{NH}_{4}^{+}$, $\mathrm{Mn}^{2+}$, and $\left.\mathrm{Fe}^{2+}\right)^{21}$ that were mixed from the anoxic water body into the entire water column during the overturn period. Nevertheless, the uncertainties in the sediment and volume uptakes remain high. Hence, the oxygen balance cannot be utilized to reliably estimate the methane oxidation rates in the water column.

In general, there is a controversial discussion about how much of the stored methane is emitted to the atmosphere and how much is oxidized during overturns in lakes. Estimates of global methane emissions assume that all of the methane stored in the water column is eventually emitted to the atmosphere, ${ }^{3}$ whereas other studies have suggested that a major fraction of the stored methane is oxidized during overturns. ${ }^{15,18,19}$ Our results provide evidence that not all of the stored methane is released to the atmosphere during the overturn period. However, the fraction of stored methane emitted to the atmosphere during overturn may be substantially larger and the fraction of stored methane oxidized may be smaller than in the previous studies suggesting high oxidation losses of methane. The latter suggests that the oxidation of methane and the 
fraction of the stored methane in the water column emitted during overturn may differ between lakes.

Studies of boreal lakes have suggested that the methane emissions during spring overturns after ice breakup are usually larger than the methane emissions during autumn overturns; ${ }^{7,17}$ however, in several cases the methane emissions during the autumn overturn were larger than the emissions during the spring overturn. ${ }^{7}$ In temperate Mindelsee, which was only intermittently and partially ice covered in the winter of 2012/ 2013 , only $\sim 140 \mathrm{~kg}$ of dissolved methane was emitted between 9 January and 24 May 2013 (Table 1). The amount of methane emitted during this time, which included ice breakup, corresponds to only $\sim 1 \%$ of the annual emissions, whereas the autumn overturn contributed $\sim 80 \%$ of the annual emissions. The latter can be explained by rapid mixing of the water column during overturn transporting upward large quantities of methane that were stored in the anoxic hypolimnion during the stratified period. These large quantities of methane in the anoxic hypolimnion result from high fluxes of methane from the sediments into the water column under anoxic conditions. Under oxic conditions, the methane fluxes from the sediments into the water column are comparatively small, as observed during the winter months in Mindelsee and also in the boreal Lake Paajarvi in southern Finland. ${ }^{17}$ The anoxic conditions in the deep water appear to be a key factor in determining the amount of methane stored in the water column that can be released during autumn overturns after a period of stratification or during spring overturns after ice breakup.

Longer periods of stratification are more likely to produce anoxic conditions in the deep water of lakes and larger quantities of dissolved methane stored in the anoxic hypolimnia, which are eventually emitted to the atmosphere during overturn periods. Climate warming is predicted to reduce the duration of ice cover and increase the duration of summer stratification. ${ }^{34}$ The latter is expected to result in the more frequent occurrence of hypoxia and an increase in the extent of existing hypoxic zones in the deep water of temperate lakes. ${ }^{35}$ As a result, the influx of methane from the sediments and the amount of methane stored in the water column of temperate lakes should increase with climate warming and result in larger emissions of methane to the atmosphere during the autumn overturn. In boreal lakes, the reduced duration of ice cover expected with climate warming may lead not only to an extension of hypoxic periods during summer stratification but also to shorter time periods with hypoxia under ice cover. Therefore, in a warmer climate, methane storage in hypoxic waters may increase during the summer but decrease during the winter, which would result in larger methane emissions during the autumn overturn and smaller methane emissions after ice breakup during the spring overturn.

Methane is the second most important greenhouse gas after carbon dioxide, ${ }^{36}$ and lakes are considered to be one of the largest natural sources to the global methane budget. ${ }^{3,4}$ The contribution of small lakes, in which the methane flux from storage accounts for most of the annual diffusive flux to the atmosphere, ${ }^{3}$ is particularly large. In temperate lakes, climate warming and methane efflux from storage during the autumn overturn may therefore be part of a positive feedback mechanism that enhances climate warming. Because the methane fluxes from the sediments into the water column depend on the conditions at the sediment-water interface, the effects of climate warming are expected to be much greater in lakes that develop an annual anoxic deep water zone than in lakes with an oxic water column throughout the year. Our results suggest that the assessment of the role of methane emissions from lakes in the global methane budget and of the potential impact of climate warming on methane emissions from lakes would benefit from distinguishing between lakes with oxic and anoxic conditions in the deep water.

\section{ASSOCIATED CONTENT}

\section{Supporting Information}

Detailed description of the boundary layer model employed and the different relationships for the gas transfer velocity applied for the calculation of the diffusive flux of methane to the atmosphere (eqs S1-S6), calculation of the decline in oxygen content with time and estimation of the areal and volumetric oxygen demands, mass balance of methane in Mindelsee with respect to the choice of the relationship for the gas transfer velocity (Tables S1-S3), and Figures S1-S6. This material is available free of charge via the Internet at http:// pubs.acs.org.

\section{AUTHOR INFORMATION}

\section{Corresponding Author}

*Phone: +49 753188 3232; fax: +49 753188 3533; e mail: hilmar.hofmann@uni konstanz.de.

\section{Notes}

The authors declare no competing financial interest.

\section{ACKNOWLEDGMENTS}

We thank J. Halder, B. Rosenberg, A. Sulger, B. Schink, and many student assistants for their help and support in the field and in the lab. Furthermore, we thank the German Weather Service (DWD) for providing wind data from station Konstanz and T. Wolf from the Institute of Lake Research (ISF) for the morphological data on the lake. The manuscript was improved by the helpful comments of three anonymous reviewers. This work was financially supported by the German Research Foundation (DFG) (Grant HO 4536/1 1) and the Young Scholar Fund (YSF) at the University of Konstanz (Grant 419/ 14).

\section{REFERENCES}

(1) Tranvik, L. J.; Downing, J. A.; Cotner, J. B.; Loiselle, S. A.; Striegl, R. G.; Ballatore, T. J.; Dillon, P.; Finlay, K.; Fortino, K.; Knoll, L. B.; Kortelainen, P. L.; Kutser, T.; Larsen, S.; Laurion, I.; Leech, D. M.; McCallister, S. L.; McKnight, D. M.; Melack, J. M.; Overholt, E.; Porter, J. A.; Prairie, Y.; Renwick, W. H.; Roland, F.; Sherman, B. S.; Schindler, D. W.; Sobek, S.; Tremblay, A.; Vanni, M. J.; Verschoor, A. M.; von Wachenfeldt, E.; Weyhenmeyer, G. A. Lakes and reservoirs as regulators of carbon cycling and climate. Limnol. Oceanogr. 2009, 54 (6), 2298-2314, DOI: 10.4319/lo.2009.54.6 part 2.2298.

(2) Battin, T. J.; Luyssaert, S.; Kaplan, L. A.; Aufdenkampe, A. K.; Richter, A.; Tranvik, L. J. The boundless carbon cycle. Nat. Geosci. 2009, 2 (9), 598-600, DOI: 10.1038/ngeo618.

(3) Bastviken, D.; Cole, C.; Pace, M.; Tranvik, L. Methane emissions from lakes: Dependence of lake characteristics, two regional assessments, and a global estimate. Global Biogeochem. Cycles 2004, 18, No. GB4009, DOI: 10.1029/2004GB002238.

(4) Luyssaert, S.; Abril, G.; Andres, R.; Bastviken, D.; Bellassen, V.; Bergamaschi, P.; Bousquet, P.; Chevallier, F.; Ciais, P.; Corazza, M.; Dechow, R.; Erb, K. H.; Etiope, G.; Fortems Cheiney, A.; Grassi, G.; Hartmann, J.; Jung, M.; Lathiere, J.; Lohila, A.; Mayorga, E.; Moosdorf, N.; Njakou, D. S.; Otto, J.; Papale, D.; Peters, W.; Peylin, P.; Raymond, P.; Rodenbeck, C.; Saarnio, S.; Schulze, E. D.; Szopa, S.; Thompson, R.; Verkerk, P. J.; Vuichard, N.; Wang, R.; Wattenbach, 
M.; Zaehle, S. The European land and inland water $\mathrm{CO}_{2}, \mathrm{CO}, \mathrm{CH}_{4}$ and $\mathrm{N}_{2} \mathrm{O}$ balance between 2001 and 2005. Biogeosciences 2012, 9 (8), 3357-3380, DOI: 10.5194/bg 933572012.

(5) St. Louis, V. L.; Kelly, C. A.; Duchemin, E.; Rudd, J. W. M.; Rosenberg, D. M. Reservoir surfaces as sources of greenhouse gases to the atmosphere: A global estimate. Bioscience 2000, 50 (9), 766-775, DOI: $10.1641 / 0006$ 3568(2000)050[0766:RSASOG]2.0.CO;2.

(6) Bastviken, D.; Tranvik, L. J.; Downing, J. A.; Crill, P. M.; Enrich Prast, A. Freshwater methane emissions offset the continental carbon sink. Science 2011, 331 (6013), 50 DOI: 10.1126/science.1196808.

(7) Juutinen, S.; Rantakari, M.; Kortelainen, P.; Huttunen, J. T.; Larmola, T.; Alm, J.; Silvola, J.; Martikainen, P. J. Methane dynamics in different boreal lake types. Biogeosciences 2009, 6 (2), 209-223, DOI: $10.5194 /$ bg 62092009 .

(8) Raymond, P. A.; Hartmann, J.; Lauerwald, R.; Sobek, S.; McDonald, C.; Hoover, M.; Butman, D.; Striegl, R.; Mayorga, E.; Humborg, C.; Kortelainen, P.; Durr, H.; Meybeck, M.; Ciais, P.; Guth, P. Global carbon dioxide emissions from inland waters. Nature 2013, 503 (7476), 355-359, DOI: 10.1038/nature12760.

(9) Smith, L. K.; Lewis, W. M., Jr. Seasonality of methane emissions from five lakes and associated wetlands of the Colorado Rockies. Global Biogeochem. Cycles 1992, 6 (4), 323-338, DOI: 10.1029/ 92GB02016.

(10) Bergström, I.; Makela, S.; Kankaala, P.; Kortelainen, P. Methane efflux from littoral vegetation stands of southern boreal lakes: An upscaled regional estimate. Atmos. Environ. 2007, 41 (2), 339-351, DOI: $10.1016 /$ j.atmosenv.2006.08.014.

(11) Bastviken, D.; Cole, J. J.; Pace, M. L.; van de Bogert, M. C. Fates of methane from different lake habitats: Connecting whole lake budgets and $\mathrm{CH}_{4}$ emissions. J. Geophys. Res.: Biogeosci. 2008, 113, No. G02024, DOI: 10.1029/2007JG000608.

(12) Bastviken, D.; Ejlertsson, J.; Tranvik, L. Measurement of methane oxidation in lakes: A comparison of methods. Environ. Sci. Technol. 2002, 36 (15), 3354-3361, DOI: 10.1021/es010311p.

(13) Schubert, C.; Lucas, F.; Durisch Kaiser, E.; Stierli, R.; Diem, T.; Scheidegger, O.; Vazquez, F.; Müller, B. Oxidation and emission of methane in a monomictic lake (Rotsee, Switzerland). Aquat. Sci. 2010, 72 (4), 455-466, DOI: 10.1007/s00027 01001485.

(14) Durisch Kaiser, E.; Schmid, M.; Peeters, F.; Kipfer, R.; Dinkel, C.; Diem, T.; Schubert, C. J.; Wehrli, B. What prevents outgassing of methane to the atmosphere in Lake Tanganyika? J. Geophys. Res.: Biogeosci. 2011, 116 (G2), No. G02022, DOI: 10.1029/2010jg001323.

(15) Schubert, C. J.; Diem, T.; Eugster, W. Methane emissions from a small wind shielded lake determined by eddy covariance, flux chambers, anchored funnels, and boundary model calculations: A comparison. Environ. Sci. Technol. 2012, 46 (8), 4515-4522, DOI: 10.1021 /es203465x.

(16) Liu, R. M.; Hofmann, A.; Gulacar, F. O.; Favarger, P. Y.; Dominik, J. Methane concentration profiles in a lake with a permanently anoxic hypolimnion (Lake Lugano, Switzerland-Italy). Chem. Geol. 1996, 133 (1-4), 201-209, DOI: 10.1016/s0009 2541(96)00090 3.

(17) López Bellido, J. L.; Tulonen, T.; Kankaala, P.; Ojala, A. $\mathrm{CO}_{2}$ and $\mathrm{CH}_{4}$ fluxes during spring and autumn mixing periods in a boreal lake (Paajarvi, southern Finland). J. Geophys. Res.: Biogeosci. 2009, 114, No. G04007, DOI: 10.1029/2009jg000923.

(18) Kankaala, P.; Taipale, S.; Nykanen, H.; Jones, R. I. Oxidation, efflux, and isotopic fractionation of methane during autumnal turnover in a polyhumic, boreal lake. J. Geophys. Res.: Biogeosci. 2007, 112 (G2), No. G02003, DOI: 10.1029/2006jg000336.

(19) Utsumi, M.; Nojiri, Y.; Nakamura, T.; Nozawa, T.; Otsuki, A.; Takamura, N.; Watanabe, M.; Seki, H. Dynamics of dissolved methane and methane oxidation in dimictic Lake Nojiri during winter. Limnol. Oceanogr. 1998, 43 (1), 10-17, DOI: 10.4319/lo.1998.43.1.0010.

(20) Karlsson, J.; Giesler, R.; Persson, J.; Lundin, E. High emission of carbon dioxide and methane during ice thaw in high latitude lakes. Geophys. Res. Lett. 2013, 40 (6), 1123-1127, DOI: 10.1002/grl.50152.

(21) ISF Arbeitsbericht 2011/2012 (Work Report of the Institute of Lake Research Langenargen); Institut für Seenforschung: Langenargen,
Germany, 2012; http://www.lubw.baden wuerttemberg.de/servlet/is/ 224625 /isf arbeitsbericht 2011 2012.pdf? command= downloadContent\&filename=isf arbeitsbericht 2011 2012.pdf.

(22) Hofmann, H.; Federwisch, L.; Peeters, F. Wave induced release of methane: Littoral zones as a source of methane in lakes. Limnol. Oceanogr. 2010, 55 (5), 1990-2000, DOI: 10.4319/lo.2010.55.5.1990.

(23) Liss, P. S.; Slater, P. G. Flux of gases across the air-sea interface. Nature 1974, 247 (5438), 181-184, DOI: 10.1038/247181a0.

(24) Liss, P. S.; Merlivat, L., Air-sea gas exchange rates: Introduction and synthesis. In The Role of Air-Sea Exchange in Geochemical Cycling; D. Reidel Publishing Company: Dordrecht, The Netherlands, 1986; pp 113-127.

(25) Wanninkhof, K. Relationship between wind speed and gas exchange. J. Geophys. Res.: Oceans 1992, 97 (C5), 7373-7382, DOI: $10.1029 / 92 J C 00188$

(26) Cole, J. J.; Caraco, N. F. Atmospheric exchange of carbon dioxide in a low wind oligotrophic lake measured by the addition of SF $_{6}$. Limnol. Oceanogr. 1998, 43 (4), 647-656, DOI: 10.4319/ lo.1998.43.4.0647.

(27) Crusius, J.; Wanninkhof, R. Gas transfer velocities measured at low wind speed over a lake. Limnol. Oceanogr. 2003, 48 (3), 10101017, DOI: 10.4319/lo.2003.48.3.1010.

(28) Guerin, F.; Abril, G.; Serca, D.; Delon, C.; Richard, S.; Delmas, R.; Tremblay, A.; Varfalvy, L. Gas transfer velocities of $\mathrm{CO}_{2}$ and $\mathrm{CH}_{4}$ in a tropical reservoir and its river downstream. J. Mar. Syst. 2007, 66 (1-4), 161-172, DOI: 10.1016/j.jmarsys.2006.03.019.

(29) MacIntyre, S.; Jonsson, A.; Jansson, M.; Aberg, J.; Turney, D. E.; Miller, S. D. Buoyancy flux, turbulence, and the gas transfer coefficient in a stratified lake. Geophys. Res. Lett. 2010, 37, No. L24604, DOI: $10.1029 / 2010 \mathrm{gl044164.}$

(30) Wiesenburg, D. A.; Guinasso, N. L., Jr. Equilibrium solubilities of methane, carbon monoxide, and hydrogen in water and sea water. J. Chem. Eng. Data 1979, 24 (4), 356-360, DOI: 10.1021/je60083a006.

(31) Hofmann, H. Spatiotemporal distribution patterns of dissolved methane in lakes: How accurate are the current estimations of the diffusive flux path? Geophys. Res. Lett. 2013, 40 (11), 2779-2784, DOI: $10.1002 /$ grl.50453.

(32) Schilder, J.; Bastviken, D.; van Hardenbroek, M.; Kankaala, P.; Rinta, P.; Stötter, T.; Heiri, O. Spatial heterogeneity and lake morphology affect diffusive greenhouse gas emission estimates of lakes. Geophys. Res. Lett. 2013, 40 (21), 5752-5756, DOI: 10.1002/ 2013 gl057669.

(33) Frevert, T. Sauerstoffzehrungsraten von Profundalsediment des Bodensee Obersees unter oxischen und anoxischen Bedingungen. Schweiz. Z. Hydrol. 1980, 42 (1), 56-64, DOI: 10.1007/bf02502506.

(34) Magnuson, J. J.; Robertson, D. M.; Benson, B. J.; Wynne, R. H.; Livingstone, D. M.; Arai, T.; Assel, R. A.; Barry, R. G.; Card, V.; Kuusisto, E.; Granin, N. G.; Prowse, T. D.; Stewart, K. M.; Vuglinski, V. S. Historical trends in lake and river ice cover in the Northern Hemisphere. Science 2000, 289 (5485), 1743-1746, DOI: 10.1126/ science.289.5485.1743.

(35) Foley, B.; Jones, I. D.; Maberly, S. C.; Rippey, B. Long term changes in oxygen depletion in a small temperate lake: Effects of climate change and eutrophication. Freshwater Biol. 2012, 57 (2), 278-289, DOI: 10.1111/j.1365 2427.2011.02662.x.

(36) IPCC Fifth Assessment Report. http://www.ipcc.ch/report/ ar5/index.shtml (accessed 11 June 2014). 


\section{Supporting Information (SI)}

\section{The importance of the autumn overturn and anoxic conditions in the hypolimnion for the annual methane emissions from a temperate lake}

Jorge Encinas Fernández, Frank Peeters, Hilmar Hofmann

The importance of the autumn overturn and anoxic conditions in the hypolimnion for annual methane emissions from a temperate lake

The Supporting Information (SI) provide a detailed description of the boundary layer model employed and the different relationships for the gas transfer velocity applied for the calculation of the diffusive flux of methane to the atmosphere.

The sensitivity of the mass balance of methane in Mindelsee with respect to the choice of the relationship for the gas transfer velocity was tested using four different empirical relations for the gas transfer velocity (Table 1 and Tables S1-S3).

Detailed information are given on the oxygen mass balance calculations.

The SI provide also additional figures on the bathymetry of Mindelsee including the sampling stations (Figure S1), the hypsographic curves (depth vs. area and volume) of Mindelsee (Figure S2), the regression between the dissolved methane concentration derived from water samples and measured by the methane probe (Figure S3), the diffusive influx of oxygen into the water column and dissolved oxygen content in Mindelsee (Figure S4), the profiles of temperature, dissolved oxygen, and dissolved methane in Mindelsee on different sampling dates throughout 2012 and 2013 (Figure S5), and the horizontal variation of the dissolved methane concentration along the main axis of Mindelsee during stable stratification in summer and during the autumn overturn (Figure S6). 


\section{Diffusive flux of methane}

The diffusive flux of methane to the atmosphere was calculated using the boundary layer model as described by Liss and Slater ${ }^{1}$

$$
F_{\mathrm{CH}_{4}}=k_{\mathrm{CH}_{4}} \cdot M_{\mathrm{CH}_{4}} \cdot\left(C_{w}-C_{e q}\right)
$$

where $F_{\mathrm{CH}_{4}}$ is the air-water flux of methane, $k_{\mathrm{CH}_{4}}$ the transfer velocity of methane, $\mathrm{M}_{\mathrm{CH}_{4}}$ the molar mass of methane, $C_{w}$ the measured near-surface water molar concentration of methane and $C_{e q}$ the molar concentration of methane in the surface water that is in equilibrium with the atmospheric concentration at surface water temperature. The transfer velocity of methane $k_{\mathrm{CH}_{4}}$ was estimated from the transfer velocity of $\mathrm{CO}_{2}$ at standard conditions $k_{600}$ (Schmidt number 600) using the relation of Liss and Merlivat ${ }^{2}$

$k_{\mathrm{CH}_{4}}=k_{600} \cdot\left(\frac{S c}{600}\right)^{n}$

where $S_{c}$ is the Schmidt number (-) of methane at water surface temperature ${ }^{3}$, and $n$ is $-2 / 3$ for $U_{10} \leq 3.7 \mathrm{~m} \mathrm{~s}^{-1}$ ) and $-1 / 2$ for $U_{10}>3.7 \mathrm{~m} \mathrm{~s}^{-1}$ ).

The gas transfer velocity $k_{600}$ was calculated using four different relationships:

(1) given by Cole and Caraco: ${ }^{4}$

$k_{600}=2.07+0.215 \cdot U_{10}^{17} \mathrm{~cm} \mathrm{~h}^{-1}$

(2) given by Crusius and Wanninkhof: ${ }^{5}$

$$
\text { for } \begin{aligned}
U_{10} & <3.7 \mathrm{~m} \mathrm{~s}^{-1} \\
k_{600} & =0.72 \cdot U_{10} \mathrm{~cm} \mathrm{~h}^{-1} \\
\text { for } U_{10} & \geq 3.7 \mathrm{~m} \mathrm{~s}^{-1} \\
k_{600} & =4.33 \cdot U_{10}-13.3 \mathrm{~cm} \mathrm{~h}^{-1}
\end{aligned}
$$

(3) given by Guerin et al.:

$$
k_{600}=1.66 \cdot e^{026 \cdot U_{10}} \mathrm{~cm} \mathrm{~h}^{-1}
$$

(4) given by MacIntyre et al.:

$$
k_{600}=2.25 \cdot U_{10}+0.16 \mathrm{~cm} \mathrm{~h}^{-1}
$$

The $C_{e q}$ of methane in the water was calculated according to Wiesenburg and Guinasso ${ }^{8}$, whereby the atmospheric concentration of methane was set to $1.8 \mathrm{ppm}$. Wind data $\left(U_{10}\right)$ were supplied by a proximate (15 km eastward of Mindelsee) weather station of the DWD (German Weather Service). 
The mass balance of methane in Mindelsee was calculated from the estimates of the diffusive flux of methane to the atmosphere based on the relationship for the gas transfer velocity given by Cole and Caraco. ${ }^{4}$

Independent from the relationship for the gas transfer velocity applied about half or more of the stored methane is released to the atmosphere, i.e. according to Crusius and Wanninkhof ${ }^{5}$, Cole and $\mathrm{Caraco}^{4}$, Guerin et al. ${ }^{6}$, and MacIntyre et al. ${ }^{7} \sim 49 \%, \sim 46 \%, \sim 50 \%$, and $\sim 87 \%$, respectively (Table 1; SI, Tables S1-S3).

\section{Mass balance of oxygen}

Assuming that areal and volumetric oxygen demands are independent of depth, the decline in oxygen content per time $\frac{\Delta \mathrm{O}_{2}}{\Delta t}$ below a certain depth $z$ can be expressed as:

$$
\frac{\Delta O_{2}}{\Delta t}=F_{O}+P_{O}-A \cdot O_{A}-V \cdot O_{V}
$$

where $F_{O}$ is the flux of oxygen at $z, P_{O}$ is the total oxygen production within the volume below $z, A$ is the area of the sediment below $z, O_{A}$ is the areal oxygen demand, $V$ is the volume below z and $O_{V}$ is the volumetric oxygen demand. To separate $O_{A}$ and $O_{V}$, the water column below $9 \mathrm{~m}$ and the entire water column were considered separately. The diffusive flux of oxygen at $9 \mathrm{~m}$ is negligible because the turbulent diffusivity is very low in this depth range under stratified conditions and therefore $F_{O}=0$ was used. When considering the entire water column, the influx of oxygen from the atmosphere was considered. The oxygen production $P_{O}$ was assumed to be negligible as the oxygen uptake between February and March 2013 and April and May 2013 were very similar. 
Table S1: Mass balance of methane in Mindelsee based on the diffusive flux estimates, which were derived from the relationship for the gas transfer velocity given by Crusius and Wanninkhof. ${ }^{5}$

\begin{tabular}{|c|c|c|c|c|c|c|c|}
\hline \multirow{4}{*}{ Time period } & \multicolumn{3}{|c|}{ Rates } & \multicolumn{4}{|c|}{ Total mass of $\mathrm{CH}_{4}$} \\
\hline & \multirow{2}{*}{$\begin{array}{l}\text { Temporal } \\
\text { change of } \\
\text { stored } \mathrm{CH}_{4}\end{array}$} & \multirow{2}{*}{\multicolumn{2}{|c|}{ Diff. $\mathrm{CH}_{4}$-flux }} & \multicolumn{3}{|c|}{ Water column storage } & \multirow{3}{*}{$\begin{array}{c}\begin{array}{c}\text { Emittec } \\
\mathrm{CH}_{4}\end{array} \\
\mathrm{~kg}\end{array}$} \\
\hline & & & & $\begin{array}{c}\text { At the } \\
\text { beginning }\end{array}$ & $\begin{array}{l}\text { At the } \\
\text { end }\end{array}$ & Diff. & \\
\hline & $\mathrm{kg} \mathrm{d}^{-1}$ & $\mathrm{mg} \mathrm{m}^{-2} \mathrm{~d}^{-1}$ & $\mathrm{~kg} \mathrm{~d}^{-1}$ & $\mathrm{~kg}$ & $\mathrm{~kg}$ & $\mathrm{~kg}$ & \\
\hline $07 / 18 / 12-10 / 25 / 12$ & 142.5 & 6.8 & 7.0 & 4,299 & 18,549 & 14,250 & 597 \\
\hline $10 / 25 / 12-11 / 28 / 12$ & 5.1 & 18.5 & 18.9 & 18,549 & 18,721 & 172 & 642 \\
\hline $11 / 28 / 12-01 / 09 / 13$ & -445.3 & 212.0 & 216.2 & 18,721 & 17 & $-18,704$ & 9,082 \\
\hline $01 / 09 / 13-05 / 24 / 13$ & 1.1 & 0.9 & 0.9 & 17 & 137 & 120 & 97 \\
\hline $05 / 24 / 13-06 / 24 / 13$ & 18.7 & 4.2 & 4.3 & 137 & 699 & 562 & 129 \\
\hline
\end{tabular}

Table S2: Mass balance of methane in Mindelsee based on the diffusive flux, which were derived from the relationship for the gas transfer velocity given by Guerin et al. ${ }^{6}$

\begin{tabular}{|c|c|c|c|c|c|c|c|}
\hline \multirow{4}{*}{ Time period } & \multicolumn{3}{|c|}{ Rates } & \multicolumn{4}{|c|}{ Total mass of $\mathrm{CH}_{4}$} \\
\hline & \multirow{2}{*}{$\begin{array}{l}\text { Temporal } \\
\text { change of } \\
\text { stored } \mathrm{CH}_{4}\end{array}$} & \multirow{2}{*}{\multicolumn{2}{|c|}{ Diff. $\mathrm{CH}_{4}$-flux }} & \multicolumn{3}{|c|}{ Water column storage } & \multirow{3}{*}{$\begin{array}{c}\begin{array}{c}\text { Emitted } \\
\mathrm{CH}_{4}\end{array} \\
\mathrm{~kg}\end{array}$} \\
\hline & & & & \multirow{2}{*}{$\begin{array}{c}\begin{array}{c}\text { At the } \\
\text { beginning }\end{array} \\
\mathrm{kg}\end{array}$} & \multirow{2}{*}{$\begin{array}{c}\begin{array}{c}\text { At the } \\
\text { end }\end{array} \\
\mathrm{kg}\end{array}$} & \multirow{2}{*}{$\frac{\text { Diff. }}{\mathrm{kg}}$} & \\
\hline & $\mathrm{kg} \mathrm{d}^{-1}$ & $\mathrm{mg} \mathrm{m}^{-2} \mathrm{~d}^{-1}$ & $\mathrm{~kg} \mathrm{~d}^{-1}$ & & & & \\
\hline $07 / 18 / 12-10 / 25 / 12$ & 142.5 & 10.4 & 10.6 & 4,299 & 18,549 & 14,250 & 1,062 \\
\hline $10 / 25 / 12-11 / 28 / 12$ & 5.1 & 24.6 & 25.1 & 18,549 & 18,721 & 172 & 852 \\
\hline $11 / 28 / 12-01 / 09 / 13$ & -445.3 & 219.8 & 224.1 & 18,721 & 17 & $-18,704$ & 9,414 \\
\hline $01 / 09 / 13-05 / 24 / 13$ & 1.1 & 1.3 & 1.3 & 17 & 137 & 120 & 140 \\
\hline $05 / 24 / 13-06 / 24 / 13$ & 18.7 & 5.1 & 5.2 & 137 & 699 & 562 & 157 \\
\hline
\end{tabular}


Table S3: Mass balance of methane in Mindelsee based on the diffusive flux estimates, which were derived from the relationship for the gas transfer velocity given by MacIntyre et al. ${ }^{7}$ Note that whose is derived from measurements with an eddy covariance technique, which may be include bubble fluxes (not reported). This could explain the much higher diffusive fluxes of methane compared to the other relationships for the gas transfer velocity.

\begin{tabular}{|c|c|c|c|c|c|c|c|}
\hline \multirow{4}{*}{ Time period } & \multicolumn{3}{|c|}{ Rates } & \multicolumn{4}{|c|}{ Total mass of $\mathrm{CH}_{4}$} \\
\hline & \multirow{2}{*}{$\begin{array}{l}\text { Temporal } \\
\text { change of } \\
\text { stored } \mathrm{CH}_{4}\end{array}$} & \multirow{2}{*}{\multicolumn{2}{|c|}{ Diff. $\mathrm{CH}_{4}$-flux }} & \multicolumn{3}{|c|}{ Water column storage } & \multirow{3}{*}{$\begin{array}{c}\begin{array}{c}\text { Emitted } \\
\mathrm{CH}_{4}\end{array} \\
\mathrm{~kg}\end{array}$} \\
\hline & & & & \multirow{2}{*}{$\begin{array}{c}\begin{array}{c}\text { At the } \\
\text { beginning }\end{array} \\
\mathrm{kg}\end{array}$} & \multirow{2}{*}{$\begin{array}{c}\begin{array}{c}\text { At the } \\
\text { end }\end{array} \\
\mathrm{kg}\end{array}$} & \multirow{2}{*}{$\frac{\text { Diff. }}{\mathrm{kg}}$} & \\
\hline & $\mathrm{kg} \mathrm{d}^{-1}$ & $\mathrm{mg} \mathrm{m}^{-2} \mathrm{~d}^{-1}$ & $\mathrm{~kg} \mathrm{~d}^{-1}$ & & & & \\
\hline $07 / 18 / 12-10 / 25 / 12$ & 142.5 & 17.5 & 17.8 & 4,299 & 18,549 & 14,250 & 1,783 \\
\hline $10 / 25 / 12-11 / 28 / 12$ & 5.1 & 39.8 & 40.6 & 18,549 & 18,721 & 172 & 1,379 \\
\hline $11 / 28 / 12-01 / 09 / 13$ & -445.3 & 380.9 & 388.5 & 18,721 & 17 & $-18,704$ & 16,317 \\
\hline $01 / 09 / 13-05 / 24 / 13$ & 1.1 & 2.2 & 2.3 & 17 & 137 & 120 & 240 \\
\hline \multirow[t]{2}{*}{$05 / 24 / 13-06 / 24 / 13$} & 18.7 & 8.9 & 9.1 & 137 & 699 & 562 & 272 \\
\hline & & & & & & Total & 19,991 \\
\hline
\end{tabular}




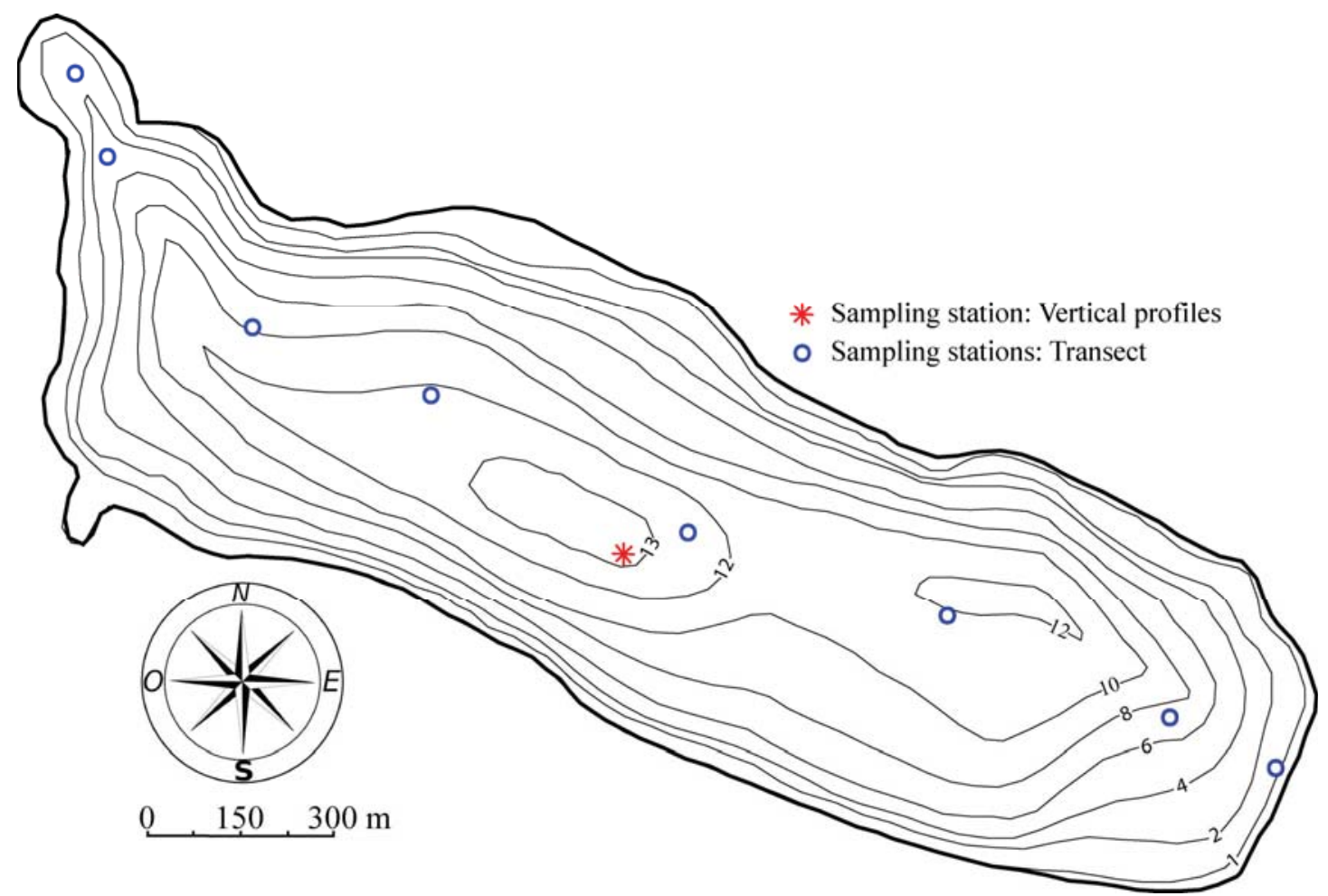

Figure S1: Bathymetric map of Mindelsee including the sampling station of vertical profiles (red asterisk) and the sampling stations of methane at $1 \mathrm{~m}$ water depth along the main axis of the lake (blue circles). 


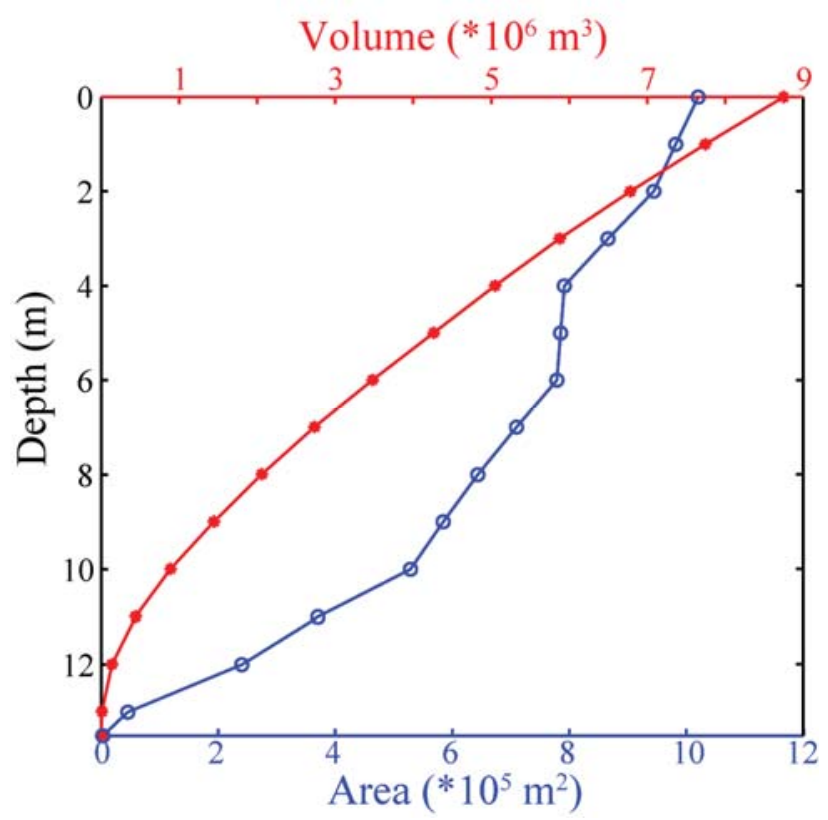

Figure S2: Hypsographic curves (depth vs. area and volume) of Mindelsee. Note that the data was provided by the Institute of Lake Research (ISF) Langenargen. 


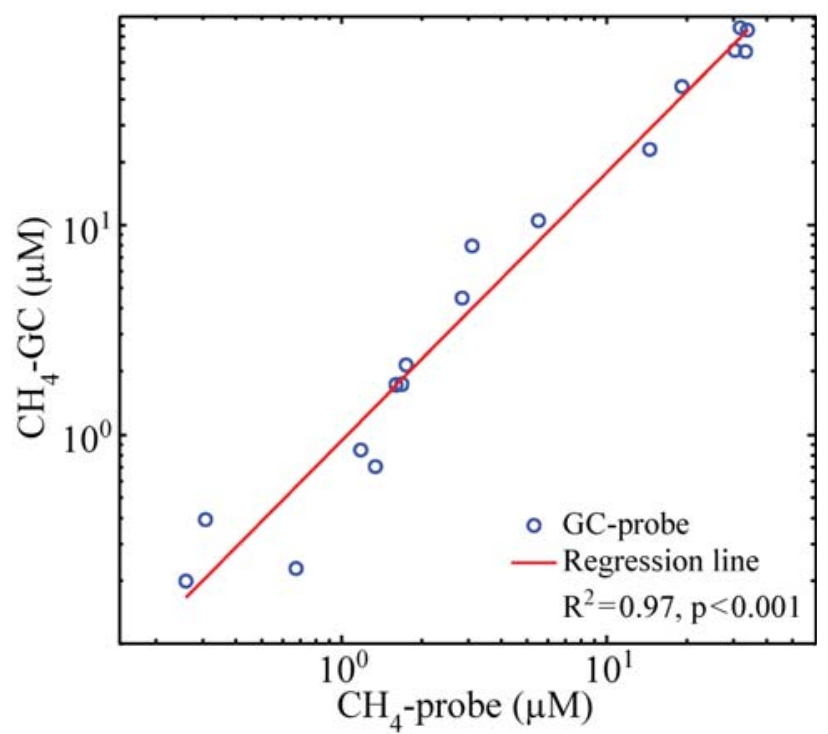

Figure S3: The probe values were calibrated to the water sample data using a linear regression of the logarithm of the probe data versus the logarithm of the water sample data. The calibrated dissolved methane concentration $\mathrm{CH}_{4, \text { cal }}(\mu \mathrm{M})$ is:

$$
\mathrm{CH}_{4, \text { cal }}=0.97 \cdot \mathrm{CH}_{4, \text { probe }}^{128}
$$

where $\mathrm{CH}_{4, \text { probe }}$ is the dissolved methane concentration $(\mu \mathrm{M})$ measured with the methane probe. 

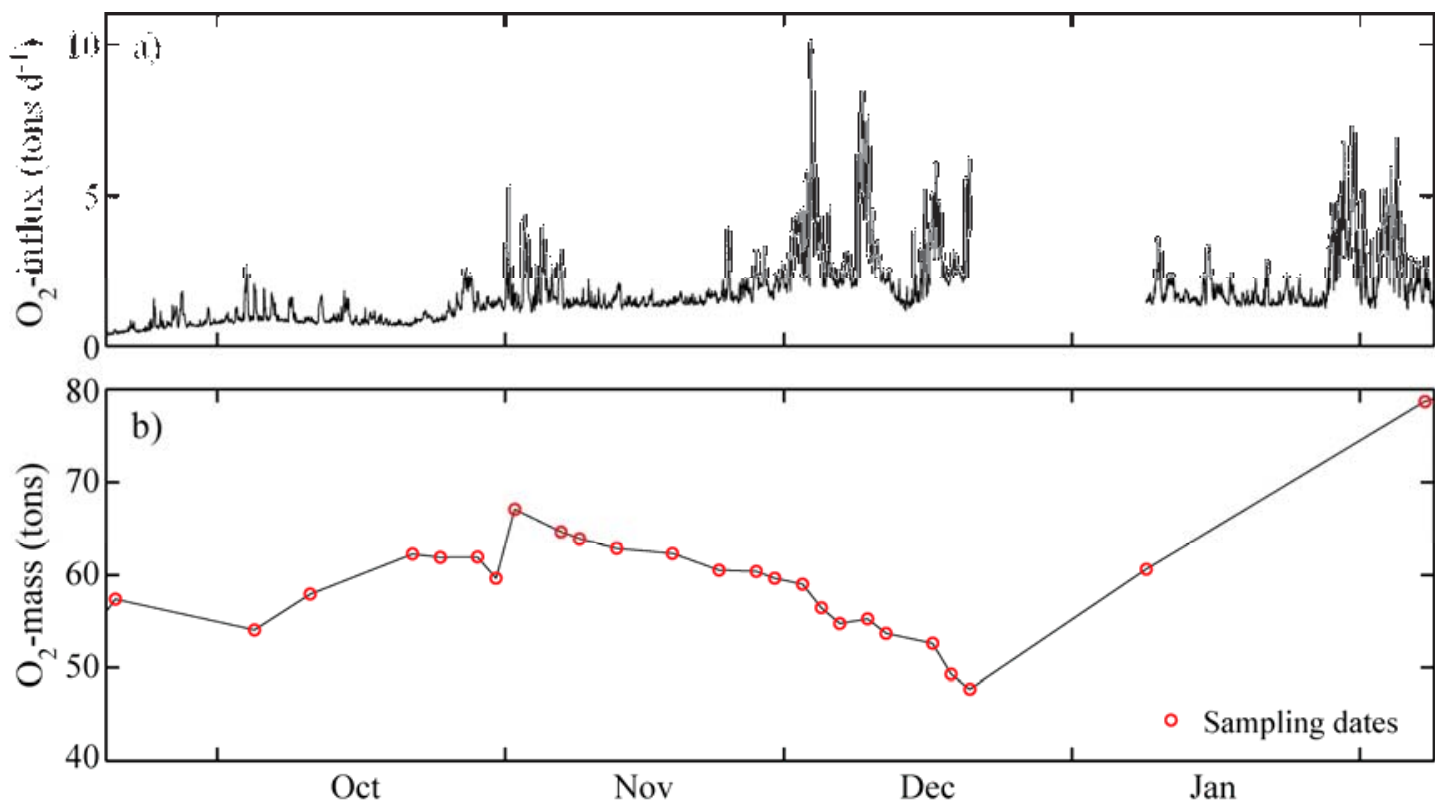

Figure S4: a) Diffusive influx of oxygen into the water column and b) dissolved oxygen content in Mindelsee between 20 September 2012 and 9 February 2013. Red points indicate the sampling dates. The course of the diffusive oxygen fluxes into the lake shows a slight increase during October 2012. Between November and December 2012, the influx of oxygen increased further. The decline in the oxygen content during the same time period indicates a high oxygen uptake in the water column during the mixing period, which was not compensated for by the influx of oxygen during this time. From the end of December the oxygen content of the lake increased rapidly. 
Diss. $\left[\mathrm{CH}_{4}\right](\mu \mathrm{M})$

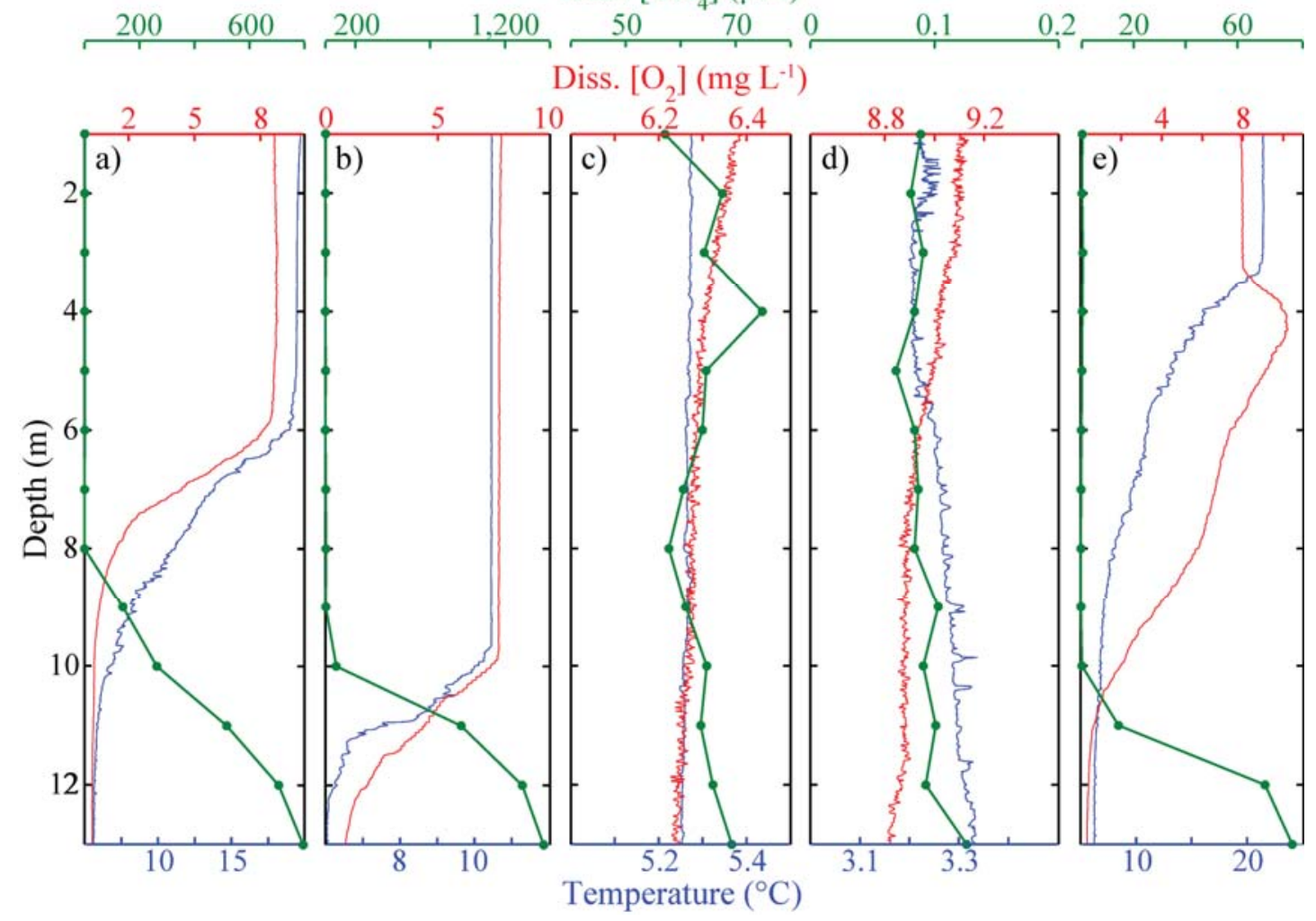

Figure S5: Profiles of temperature, dissolved oxygen, and dissolved methane in Mindelsee on different sampling dates: a) 17 September 2012, b) 7 November 2012, c) 10 December 2012, d) 8 February 2013, and e) 24 June 2013. During the stratification period (panel a) the lake was hypoxic below $8 \mathrm{~m}$ and anoxic in the deep water. During the first mixing event (panel b) the upper boundary of the hypolimnion shifted downwards to $\sim 10 \mathrm{~m}$. During the overturn (panel c), temperature, dissolved methane, and dissolved oxygen held nearly constant throughout the water column, indicating effective vertical mixing of the entire water column. During the winter mixing period (panel d), the dissolved methane concentrations were low in the entire water column and the diffusive fluxes of methane were also low (Table 1). At the beginning of the stratification period (panel e), the deep water had become anoxic but the thermocline and oxycline were still rather weak and extended down to $\sim 4 \mathrm{~m}$. The dissolved methane concentration had increased in the deep anoxic water zone, but the maximum concentrations were still ten times less than on 18 July 2012. This may have been caused by the extremely cold and cloudy spring of 2013, which delayed stable stratification by several weeks. 


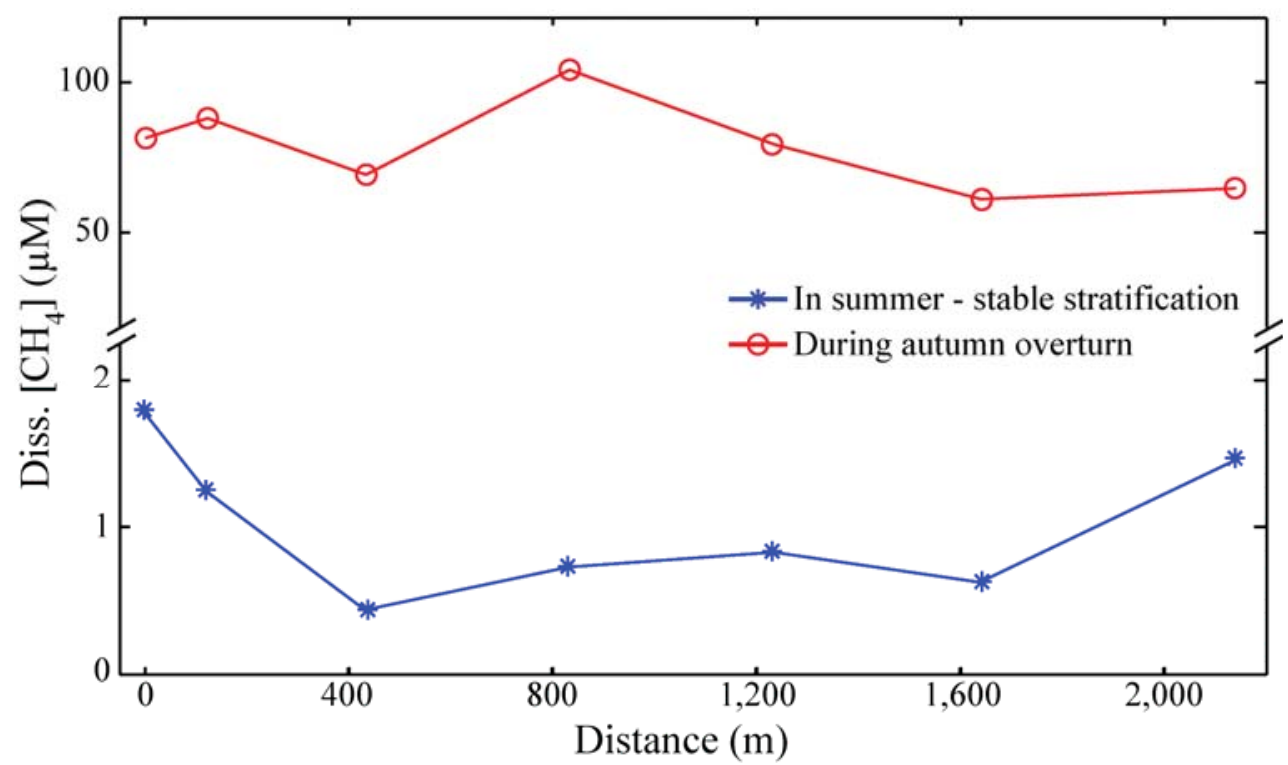

Figure S6: Near-surface (at $1 \mathrm{~m}$ water depth), horizontal variation of the dissolved methane concentration measured along the main axis of Mindelsee during stable stratification in summer (10 August 2012; blue line with asterisk) and during the autumn overturn (7 December 2012). 


\section{References}

(1) Liss, P. S.; Slater, P. G., Flux of gases across the air-sea interface. Nature 1974, 247, (5438), 181-184; doi:10.1038/247181a0.

(2) Liss, P. S.; Merlivat, L., Air-sea gas exchange rates: Introduction and synthesis. In The Role of Air-Sea Exchange in Geochemical Cycling, D. Reidel Publishing Company: Dordrecht, 1986; pp 113-127.

(3) Wanninkhof, K., Relationship between wind speed and gas exchange. J. Geophys. Res. 1992, 97, (C5), 7373-7382.

(4) Cole, J. J.; Caraco, N. F., Atmospheric exchange of carbon dioxide in a low-wind oligotrophic lake measured by the addition of $\mathrm{SF}_{6}$. Limnol. Oceanogr. 1998, 43, (4), 647656.

(5) Crusius, J.; Wanninkhof, R., Gas transfer velocities measured at low wind speed over a lake. Limnol. Oceanogr. 2003, 48, (3), 1010-1017.

(6) Guerin, F.; Abril, G.; Serca, D.; Delon, C.; Richard, S.; Delmas, R.; Tremblay, A.; Varfalvy, L., Gas transfer velocities of $\mathrm{CO} 2$ and $\mathrm{CH} 4$ in a tropical reservoir and its river downstream. J. Mar. Syst. 2007, 66, (1-4), 161-172; doi:10.1016/j.jmarsys.2006.03.019.

(7) MacIntyre, S.; Jonsson, A.; Jansson, M.; Aberg, J.; Turney, D. E.; Miller, S. D., Buoyancy flux, turbulence, and the gas transfer coefficient in a stratified lake. Geophys. Res. Let. 2010, 37, L24604; doi:10.1029/2010g1044164.

(8) Wiesenburg, D. A.; Guinasso Jr., N. L., Equilibrium solubilities of methane, carbon monoxide, and hydrogen in water and sea water. J. Chem. Eng. Data 1979, 24, (4), 356360. 